\title{
Public-private co-operation and judicial review A case study drawn from European infrastructure projects
}

\author{
Yseult Marique and Steven Van Garsse ${ }^{1}$
}

\begin{abstract}
National administrative law traditions are changing under the influence of socio-economic factors and the Europeanisation of legal norms. To illustrate this evolution this paper discusses the roles of judges in three European major transport infrastructure projects in England, France and Belgium where long-term public-private co-operation was developed and strong public opposition voiced. Public-private co-operation to develop infrastructure projects is not new. EU financial requirements and EU procurement directives, though, constrain more than ever how these public-private co-operations can be contractually designed, while EU sectoral legislation may offer new opportunities for public-private co-operation. In parallel, citizens are entitled to be involved in large projects affecting the environment and no longer mainly seek protection for their individual property rights. These changes illustrate the changing role of private parties (economic actors and citizens) in major infrastructure projects. They also result in public bodies endorsing an increasingly supervisory and monitoring role while not having the suitable skills, resources or information in-house to do so. These adaptations under the pressure of socioeconomic and political concerns call for administrative law to revisit the role that judges play in adjudicating issues arising from these complex public-private contracts, where public bodies and private parties are locked together for a long term and where changing the relationship is extremely expensive for the public purse.
\end{abstract}

\section{$\underline{\text { KEY WORDS }}$}

Public contracts; public-private partnerships; judicial review; accountability; comparative administrative law (England, France, Belgium)

\footnotetext{
1 Yseult Marique, University of Essex, Senior Lecturer; FöV Speyer, Research Associate (ymarique@essex.ac.uk); Steven van Garsse, University of Hasselt and University of Antwerp, Professor (steven.vangarsse@uhasselt.be). In an earlier stage of this research Marique benefitted from a British Academy/Leverhulme small grant. We gratefully acknowledge the feedback we received from participants at the Fifth Annual Conference of the Cambridge Journal of International and Comparative Law on Public and Private Power (April 2016), at the Fifth International Public-Private Partnerships Conference (November 2016, Antwerp) and at the panel The Changing nature of the public administration: what role of judicial review?, organized by Dr C. Colombo and Dr. M. Eliantonio at the I-Conn Conference 2017 (July, Copenhagen). Dr P. Lancos and Dr E. Tauchinsky have also provided thoughtful comments on a draft. All errors remain ours. All internet links were last consulted on January 21st, 2018.
} 


\section{Introduction}

$2018,18^{\text {th }}$ January, Prime Minister's Questions (Westminster). Following the announcement that Carillon, a UK major government's contractor, has gone into administration the Prime Minister replied to a question asked by Opposition Leader Jeremy Corbyn:

“[...] the Government's job is to ensure that public services continue to be provided [...]. The right hon. Gentleman said earlier that it was the Government's job to ensure that Carillion was properly managed, but we were a customer of Carillion, not the manager of Carillion - a very important difference. It is also important that we have protected taxpayers from an unacceptable bail-out of a private company". ${ }^{2}$

This quote mirrors the questions surrounding the role of government when selecting and monitoring private contractors providing public services and infrastructures whilst preserving taxpayers' money. The framework within which European governments decide to engage in public-private co-operations to deliver services and infrastructures has evolved over time. Comparative law reveals how strongly public-private co-operation enabling the development of major infrastructures (railways, bridges, tunnels, etc.) and their judicial review pertain to the specificities of domestic administrative law. For instance, England and France are mirror opposites while Belgium offers an interesting intermediary system. In England the liberal laissezfaire of the $1^{\text {th }}$ century led to public-private co-operation being regulated mostly through private law, with little distinctive administrative law being developed by courts. By contrast, French judges developed legal principles regulating public contracts (e.g. concessions) at the turn of the $20^{\text {th }}$ century, from which key administrative law principles were then derived. In Belgium ordinary judges struggled for a long time to review decisions awarding concessions (e.g. railways): these decisions were sovereign acts falling outside judicial review. Yet, judges were more comfortable adjudicating disputes arising from contractual performance, where they applied private law.

This historical background leaves out entrenched features in domestic administrative law and how major investment projects involving public-private co-operation are developed in 2018. For example, the 600 projects included in the UK National Infrastructure Delivery Plan for 2016$2021^{3}$ need to meet an array of planning, legal or budgetary requirements whose roots often date back to the 19th century. Yet, these major infrastructure projects are now also part of global investments. Multinational companies compete to build these railways, bridges and tunnels. Concerns about environmental protection and fiscal constraints resulting from the need to balance public budgets need to be factored in. ${ }^{4}$ In practice, two distinct but interrelated phenomena can be observed. First, large economic actors take over increasing numbers of tasks in the delivering of infrastructure projects over a long period of time (including legal, technical

\footnotetext{
${ }^{2}$ Hansard, Commons Debates, 17 January 2018, vol. 634.
}

3 Infrastructure and Projects Authority, National Infrastructure Delivery Plan 2016-2021, 2016, p. 23. Similar pipelines exist in France and Belgium. République française, Le Grand plan d'investissement, 20182022, 2017; Région wallonne, Plan Infrastructures 2016-2019, 2016; Vlaamse Regering, Beleidsnota 20142019: Mobiliteit en Openbare Werken, Vl. Parl., (2014-2015), St. 152/1). The European Union financially supports major transport infrastructure projects for 2016-2020, with direct benefits for Belgium, France and the United Kingdom: https://ec.europa.eu/transport/themes/infrastructure/ten-tguidelines/project-funding_en.

${ }^{4}$ In the case of Belgium and France this results from the Maastricht criteria set up to organize the European economic and monetary Union (Article 126(2) Treaty on the Functioning of the European Union; Protocol ( $n r$ 12) on the excessive deficit procedure). The United Kingdom was undecided about joining this system for a long time and now seeks to keep the budget balanced for political reasons. 
and financial advice to public bodies). Secondly, citizens voice their environmental, social or personal concerns regarding infrastructure projects, meaning that they become involved in their overall design and implementation. These two phenomena result in public authorities seeing their role in these complex projects changing dramatically from delivering services connected to public infrastructures to initiating, mediating, steering and supervising these projects with little in-house expertise to do so.

Economic, political and legal developments have also a major consequence for public-private cooperation: the time-frame within which major infrastructure projects are designed, delivered and maintained has been extended as each step of the process requires careful consideration and engagement with multiple stakeholders, and is likely to face legal challenges and/or public resistance. Timing is also crucial as political decision-makers may be prone to engage in major infrastructure projects to reap electoral benefits in the hope that they are unlikely to be the ones to be called to account if and when problems arise down the line. Time is also key when it comes to dealing with issues arising from these infrastructure projects: any delays incurred by the project because of lingering disputes and legal uncertainty are costly. This calls therefore for reassessing judges' role in policing infrastructure projects that affect the life quality of their neighbours and users.

When it comes to specific matters encapsulating these evolutions the most prominent debates in the legal scholarship most often relate to the scope of competition between economic actors, 5 the need for more democratic legitimacy and state-centred intervention ${ }^{6}$ or the appropriate level of regulation (European vs. national). ${ }^{7}$ However, this paper takes a different starting point, namely the factual situation on which major infrastructure projects are predicated. They all require a high level of co-operation between public and private actors over an extended duration (often more than twenty years) while in many instances encountering strong opposition from local residents (the NIMBY reaction), users and/or interest groups (e.g. environmental or professional organizations). This paper investigates the tension arising between this extensive collaboration (to pursue economic objectives) and these intense conflicts (with social and political forces claiming that the common good needs to be more inclusive).

This tension raises the question of what role judges play in adjudicating issues arising in major infrastructure projects. Hence this paper contributes to the discussions about new developments in new administrative law. This is based on a micro-comparison of selected case studies of major transport infrastructures at the interface between local, national and European law, illustrating the changing role of public bodies, private parties and judges in Belgium, England and France. England and France are indeed polar opposites when it comes to their approaches to government contracts (the legal category under which public private co-operations fall), ${ }^{8}$ while Belgium is an interesting mix of the two.

This paper is structured as follows. Section 2 explains the changes shaping the main features of public-private co-operation. Sections 3,4 and 5 then illustrate how long-term public-private cooperation is currently organised with case studies drawn from transport infrastructures in, respectively, England, France and Belgium. These sections especially focus on the role played by

${ }^{5}$ A. Sanchez-Graells, Public Procurement and the EU Competition Rules (2nd edn, Oxford Bloomsbury 2015).

${ }^{6} \mathrm{~S}$. Arrowsmith, 'The purpose of the EU procurement directives: Ends, means, and the implications for national regulatory space for commercial and horizontal procurement policies', 14 Cambridge Yearbook of European Legal Studies 1 (2011-12); P. Kunzlik, Neoliberalism and the European public procurement regime', 15 Cambridge Yearbook of European Legal Studies 283 (2012-13).

${ }^{7}$ Arrowsmith, above (n 6).

${ }^{8}$ A. C. L. Davies, The public law of government contracts (OUP 2008) 55-58. 
judges in addressing the tensions arising from these infrastructure projects. Section 6 brings together the lessons that can be drawn from comparing these case studies to suggest how judges could contribute meaningfully to the scrutiny of long-term public-private co-operation.

\section{New dynamics in public-private co-operation: shifting risks back and forth}

This section depicts the historical background within which public-private co-operation takes place and the parallel development of administrative law. ${ }^{9}$ Whilst public and private actors have long interacted to develop major transport infrastructures, the legal principles regulating these relationships and the respective roles of parliaments, executives and judges have very much fluctuated. Public-private co-operation is indeed not new in its principle but modalities are. Administrative law is both shaping these new modalities and seeking to catch up with them. Broadly speaking three main stages can be distinguished, building on each other as layers upon layers.

In a first period of development of administrative law, i.e. during the economic liberalism presiding over the Industrial Revolution, individual freedom was pivotal. The administration was supposed to be an expert acting as an agent of the legislature (in a representative democracy). Judges were there to prevent unlawful unilateral administrative decisions encroaching on individual freedoms or private property. At the time economic actors shouldered investment in infrastructure such as railways. ${ }^{10}$ Yet, this fragmented system led to market failures as risks were not managed well by private actors, leading to financial difficulties. By the late $19^{\text {th }}$ century Belgium, England and France had regulated the development of these infrastructures ${ }^{11}$ and issued increasingly detailed regulations in a range of economic sectors (e.g. railways, banking etc.) whilst recognizing some of the social demands for more protection of workers (e.g. trade unions, freedom of association, work safety regulation). The government's role grew as specific (public) bodies dealt with inspection, administrative authorizations, etc. ${ }^{12}$ Despite different models of administrative justice in the three countries lawyers and judges overall played a key role during this first phase of development, ensuring that the administration worked according to the legality principle. ${ }^{13}$

The birth of the welfare state characterizes the second period of administrative law: it resulted in a reorganization of the state. The government expanded to include organized interests in administrative decision-making (e.g. consultation, committees). The government, departments and public agencies undertook numerous new functions: they first became more active in providing public goods and services that individuals could not provide individually for themselves. After WWII their activities expanded again and led to the social welfare state: the

\footnotetext{
9 For an extended account of changes in administrative law, see F. Bignami, 'From expert administration to accountability network: A new paradigm for comparative administrative law', 59 American Journal of Comparative Law 859 (2011).
}

10 E.g. in France: X. Bezançon, 2000 ans d'histoire du partenariat public-privé (Paris, Presses de l'école nationale des ponts et chaussées 2004) 183-229.

11 See e.g. P. Errera, Traité de droit public belge (Paris, Giard et Brières 1909) 624-30 (Belgium is one of the earliest continental countries to have developed railways).

12 C. Harlow and R. Rawlings, Law and Administration (3rd edn, CUP 2009) 50-51.

13 Even in England, despite the Diceyan myth. See: C. McCormick, 'Standards of judicial review of administrative action in the United Kingdom (1890-1910)', workshop 'Fin de siècle' administrative law: Judicial standards for public authorities - 1890-1910, December 2017, organized by G. della Cananea (Rome), on file with the authors. 
government played a key role in promoting the economic and social well-being of citizens, protecting them against vulnerable conditions of youth, old age, sickness, disability and unemployment. ${ }^{14}$ The administration's decision-making, policy-making and public service delivery were guided by detailed laws, regulations and administrative procedures ${ }^{15}$ implemented in a bureaucratic, hierarchical and centralised context. Major infrastructure projects were included in this approach. As public bodies were directly exercising their economic powers in the economy (through funding and contracts, also called "dominium") attention started to be paid to ways of ensuring the political accountability of this kind of public economic activity. ${ }^{16}$

The third period of administrative law starts in the late sixties/early seventies when the economic circumstances showed the limits of the economic policies carried out after WWII. The 1973 oil crisis especially required Western industrialized states to adapt their previous economic policies to secure economic growth, coordinate investments and maintain overall social wellbeing. Keynesian ideas were no longer successful at addressing these new challenges. ${ }^{17}$ They slowly made room for Hayek's ideas: the danger of state intervention in the economy started to be echoed in the political world.18 Indeed, as the economic circumstances changed, the ideology of political parties also changed. For example, Margaret Thatcher initiated reforms regarding the size of the government in the UK. Some sectors were liberalized; privatization became the main road to economic development; budgetary cuts in the public sector led to increasing private investment in major infrastructure projects.

This new trend evolved into a broader concept where government had to be "reinvented".19 Citizens became customers, and theories such as new public management were implemented in the administration: the public sector was reformed based on approaches drawn from the private sector; audit and external agencies were developed; value for money assessments and cost-benefit analyses were undertaken to identify outsourcing options. Efficiency became paramount for public action. Involving the private sector extensively in public projects became necessary. As public bodies did not have the financial means to invest in public infrastructure themselves they needed to rely on private investments to secure the realization of public projects.

Moreover, the implementation of the European (Monetary) Union and associated budgetary constraints encouraged public bodies to look for new organizational forms that would help them keep their deficit under control. ${ }^{20}$ This reinforced the incentives for public actors to involve the private sector in their major infrastructure projects and especially in their financing. Yet, EU procurement directives constrain which contractors public bodies are able to choose as award procedures and selection criteria are tightly regulated.21

\footnotetext{
${ }^{14}$ Social insurance and allied services [1942-43 Cmd. 6404] (Beveridge Report).

15 P. Cane, Controlling administrative power - An historical comparison (CUP 2016) 39-46.

${ }^{16}$ T. Daintith, 'Regulation by contract: The new prerogative', 32 Current Legal Problems 41 (1979).

${ }^{17}$ M. Mazower, Dark continent - Europe's twentieth century (London Penguin 1998) chapter 10.
}

18 The road to serfdom (London Routledge 1944).

19 D. Osborne and T. Gaebler, Reinventing government: How the entrepreneurial spirit is transforming the public sector (Reading, Addison-Wesley 1992).

${ }^{20}$ G. Pagano et al., 'Les investissements publics à l'épreuve des normes européennes: les cas du tram de Liège, de CITEO et de l'Oosterweel', (nr 2328) Courrier hebdomadaire du CRISP 5 (2017).

${ }^{21}$ S. Arrowsmith, The Law of Public and Utilities Procurement (3 ${ }^{\text {rd }}$ edn, Sweet and Maxwell 2014). 
These changes transformed the role of private parties (economic actors and citizens) in major infrastructure projects. They gave rise to innovative investment techniques in major projects in the 1990s with the Private Finance Initiatives in England, "contrat de partenariat" (partnering contracts or public-private partnerships) in France, and Design-Build-Finance-Manage contracts in Belgium. ${ }^{22}$ Although the contractual modalities of these new techniques are tailored to each specific project they all rely on long-term contracts between public and private actors. They illustrate a major trend in administrative law and practice at that time: the idea of (more) cooperation between public and private partners, of creating more horizontal relations, of sharing tasks and risks, of equality between partners rather than unilateral action taken by public partners. Accounting techniques were used to shift the risks of the projects off the public balance sheet. ${ }^{23}$ At the same time European law became increasingly influential and strongly affected classic national administrative law. For example, EU procurement directives limit how public contracts can be amended even though changing circumstances may call for adapting the contract. ${ }^{24}$

A range of consequences ensue for public bodies. First, their role is changing as they engage in these public-private co-operations. Such co-operation requires extensive expertise in financial and economic engineering to set up the complex contractual relationships at their core. However, public bodies do not have this in-house so they seek external expertise to advise them on their projects. This means that they are not well equipped to analyse situations independently and to anticipate or respond to changing circumstances from their own motion. Secondly, private parties and their financial backers seek to minimise the actual risks that they are taking, leading to a situation where contractual terms for termination or financial guarantees are designed to ensure that major infrastructure projects are secure investments for private actors. Thirdly, major infrastructure projects as they are currently developed present a contradiction: on the one hand, they need to be flexible to adapt to changing circumstances; on the other hand, their contractual rigidity is built in to cater for any possible risk to which the project could be exposed, making the project more expansive in the negotiation stage and in the case of re-negotiation or termination. Overall, public bodies endorse an increasingly supervisory and monitoring role while not having the suitable skills, resources or information to do so.

The political consequences of choosing long-term public-private co-operation to deliver major infrastructure projects can arise long after the political decision-makers are gone, challenging the idea that these projects are carried out with full political accountability. This time lag between contractual design and supervening problem entails that the very people who are at the source of the contractual design have moved away, cannot be called to account and do not learn from their mistakes. As it stands the law does not provide for any solution to this problem, feeding into the distrust that citizens may have towards major infrastructure projects. Resistance from users and the public at large follows from this. The benefits of these projects are not understood, while the immediate personal drawbacks (noise, loss of home, destruction of local communities and/or protected natural areas etc.) are all too clear, as is the apparently reduced role of public bodies.

\footnotetext{
${ }^{22}$ For a detailed analysis and comparison: see Y. Marique, 'An English legal perspective on public-private partnerships', 95-165; S. Van Garsse and S. Wyckaert, 'Les partenariats public-privé en Belgique', 183-212; F. Lichère, 'Les partenariats public-privé en droit français', 307-332, in Public-Private Partnerships - Reports of the XVIIIt Conference of the Academy of Comparative Law (F. Lichère ed, Brussels Bruylant 2011).

${ }^{23}$ NAO, PFIs and PF2 (2017-19 HC 718) para 1.14; Eurostat, $A$ Guide to the Statistical Treatment of PPPs, 2016.

${ }^{24}$ E.g.: Directive 2014/24/EU of the European Parliament and of the Council of 26 February 2014 on public procurement.
} 
Overall, these main features of public-private co-operation are present in Belgium, France and England although their modalities vary, as discussed in the case studies below. New administrative structures are emerging to regulate these complex relationships between public bodies, economic actors and citizens. This shifting has led to changes in judges' roles as the opportunities for them to intervene have evolved. The next three sections analyse these changes in three case studies where these tensions between co-operation and opposition have arisen.

\section{High Speed 2 (England)}

England is home to the most important transport infrastructure project currently being developed in Europe with the building of High Speed 2 (HS2), a rail project linking London with Northern England (Birmingham, Manchester and Leeds). This project is being developed in stages, with completion planned for 2033 and a total budget of ca. $€ 50$ billion. ${ }^{25}$ Rail tracks need to cross protected areas (e.g. the Chilterns) and a range of properties need to be purchased. Trains should run at $250 \mathrm{miles} /$ hour (i.e. $400 \mathrm{~km} /$ hour). This project has three main objectives: firstly, encouraging economic balance between London and Northern England; secondly, fostering urban regeneration around the new train stations; and thirdly, improving travel time to and from London for commuters, offering a more comfortable working environment in the new trains. This section sets out how the public-private co-operation has been organized and how public resistance to it has been expressed.

To develop this public-private co-operation the Department for Transport (DfT) set up a nondepartmental body, HS2 Ltd.26 The DfT acts as the sponsor responsible for investment decisions and gives policy directions to HS2 (e.g. deciding on rail works regulation; how the railway is owned, operated, and maintained; interdependencies with other transport policies). It sponsors the HS2 bill in Parliament and it owns and funds HS2 Ltd. In turn, HS2 Ltd. is in charge of the technical sides of the project, namely of designing routes (compliance with technical, environmental and construction standards), of carrying out environmental impact assessments and of engaging with national bodies, local authorities and local communities. The actual work of designing the systems and building the rail tracks, stations, bridges, tunnels and hangars is carried out by engineering and building companies selected following a procurement procedure. In July 2017 a first batch of four contracts for $£ 6.6$ bn were awarded: one to Skanska, Costain and Strabag; one to Bouygues, VolkerFitzpatrick and Sir Robert McAlpine; one to Balfour Beatty and VINCI; and the last one to Kier, Eiffage and Carillon. ${ }^{27}$

Developing this project entails complying with a range of legal requirements ${ }^{28}$ and dealing with citizens' complaints arising from this public-private co-operation. One of the most crucial requirements includes the adoption of a hybrid bill by Parliament. ${ }^{29}$ Following a specific procedure dating back to the $19^{\text {th }}$ century ${ }^{30}$ a hybrid bill grants public bodies (here the DfT and

25 Economic Affairs Committee, Economics of High Speed 2 (2014-15 HL 134) 5.

${ }^{26}$ NAO, Progress with preparations for High Speed 2 (2016 HC 235) figure 4.

27 https://www.gov.uk/government/news/first-big-hs2-contracts-to-build-britains-new-railway-willsupport-16000-jobs.

28 V. Jenkins, 'Planning for major infrastructure in England: Front-loading participation in the interests of efficiency', in Quality and speed in administrative decision-making: Tension or balance?, 83 (C. Backes and M. Eliantonio eds., Cambridge, Intersentia, 2016).

29 The High Speed Rail (London - West Midlands) Act 2017 is the first bill adopted. Further bills need to be adopted for the next stages of the project. 
HS2 Ltd) the necessary powers to buy the property where the tracks are being laid and to undertake all necessary steps for allowing contractors to carry out works. ${ }^{31}$ The procedure follows the elaboration of an ordinary bill, including readings, committee, plenary vote and adoption in the two Chambers. However, a step is added in the House of Commons and the House of Lords: ${ }^{32}$ individuals who have an interest are entitled to lodge a petition to make their interests known and to be heard by a dedicated commission whose objective is to find a solution for the petitioners. ${ }^{33}$ In the case of the HS2 2,600 petitions have been lodged in the House of Commons and ca. 300 in the House of Lords. In many cases the developer has come forward with settlement proposals and the commission has not actually had to recommend a solution.

In this way the hybrid bill allows for individual claims to be addressed without any judicial intervention. Yet, HS2 has been developed in a controversial context filled with legal, economic and political issues ${ }^{34}$ such as the application of European requirements relating to environmental impact assessments, the need to compensate residents for the loss of their property and the need to audit how public money is spent.

Furthermore, major infrastructure projects such as HS2 are not a one-shot purchasing operation by public bodies. At the core of the public-private co-operation lies the development of a public infrastructure with wide socio-economic and political implications not only at one single moment in time but for the next twenty years if not longer. The private contractors have an extensive operational role. This makes public-private co-operation distinctive in terms of public bodies' needs to manage changes and crises. Issues arising of the public-private co-operation and their creative problem-solving can be illustrated with formal and informal techniques.

Firstly, an "independent HS2 construction commissioner" was set up to sort out issues arising between the different actors and with the communities affected by the construction. Secondly, the spending of taxpayers' money is tightly controlled by the National Audit Office (NAO). For instance, the NAO refused to certify HS2 Ltd.'s accounts for 2016-17: a departure from the regular rules for redundancy asked for by HS2 Ltd had been refused by the DfT but this was not complied with by HS2 Ltd., resulting in generous redundancy payments. ${ }^{35}$ This prompted the DfT to ask for a governmental audit, which it published and shared with the public accounts committee (PAC). ${ }^{36}$ More systematically, the NAO also questioned the economic assessment of the project. ${ }^{37}$ This was then followed up by PAC discussions and reports. ${ }^{38}$ The House of Lords also reported on the

${ }^{30}$ R. Perceval, The origin and essence of hybrid bill, 2(1) Parliamentary Affairs, 139, 142-43 (1949).

${ }^{31}$ High Speed Rail (London - West Midlands) Act 2017 sections 1 and 4 especially.

32 House of Commons Library, Hybrid Bills: House of Commons Background Paper, SN/PC/6736, 2013, available at http://researchbriefings.parliament.uk/ResearchBriefing/Summary/SN06736.

${ }^{33}$ See Petition Kit, House of Lords: http://www.parliament.uk/documents/Lords-HS2/House-of-LordsHS2-petitioning-kit-guide.pdf.

${ }^{34}$ Select Committee on the High Speed Rail (London - West Midlands) Bill, High Speed Rail (London - West Midlands) Bill (83 HL 2016-17) 4.

35 NAO, Report of the Comptroller and Auditor General on the 2016-17 Accounts of High Speed Two (HS2) Limited; PAC, High Speed 2 Annual Report and Accounts (2017-19 HC 454).

${ }^{36}$ DfT, High Speed 2 Limited - Annual Report and Accounts, 25 $5^{\text {th }}$ October 2017.

${ }^{37} \mathrm{NAO}$, High Speed 2 - A review of early programme preparation (2013 HC 124); Progress with preparations for High Speed 2 (2016 HC 235). 
economic case of the HS2.39 These reports flagged up a range of issues, such as the delays in adopting the hybrid bill, 40 the uncertainty regarding the route to be adopted for part of the project and the uncertain public or private funding for trains and hangars. ${ }^{41}$

Finally, problems arising from changing circumstances are illustrated in HS2 with the Carillon crisis. Carillon, one of the contractors selected in HS2, went into administration in January 2018, six months after being selected. Political questions arise concerning identifying how the DfT had chosen a contractor in financial difficulties although it performed numerous public contracts in England. Prime Minister May acknowledged this when she said:

"If the Government pulled out of contracts, [...] whenever a profit warning was issued, that would be the best way to ensure that companies failed and jobs were lost. It would also raise real issues for the Government about providing continuing, uninterrupted public services. Yes, we did recognise that it was a severe profit warning, which is why we took action in relation to the contracts that we issued. We ensured that all but one of those contracts was a joint venture. What does that mean? It means that another company is available to step in and take over the contract." 42

This pragmatic answer triggers a range of legal questions. For instance, under procurement law a change of contractor is subject to conditions. ${ }^{43}$ Even in the case of insolvency no substantial changes to a contract should be carried out when a new contractor replaces an insolvent one. Furthermore, Carillon seems to have developed a business practice of making low bids to win contracts so that it could pay its mounting debts with the new money.44 If this were confirmed questions might be raised about the financial conditions of the HS2 contract awarded to Carillon, in joint venture with Kier and Eiffage, and the government's awareness of the overall scheme might come under scrutiny. Although private contractors are contractually supposed to bear wide risks the actual bearer of risks in the last resort when financial trouble arises is the public purse. A parliamentary inquiry has been immediately called. ${ }^{45}$ Political accountability of this kind is triggered once a problem has arisen however. It does not prevent legal, financial or political risks. In light of the high financial risks in major infrastructure projects public-private co-operation needs to be on a stronger footing: social learning from both the co-operation itself and lessons to be drawn from similar projects might be the way forward. 46

38 PAC, High Speed 2 - A review of early programme preparation (2013-14 HC 478); Progress with preparations for High Speed 2 (2016-17 HC 486).

${ }^{39}$ Economic Affairs Committee, Economics of High Speed 2 (2014-15 HL 134).

${ }^{40}$ NAO, Progress with preparations for High Speed 2 (2016 HC 235) 6.

${ }^{41}$ Ibid. 28; PAC, Progress with the preparation for High Speed 2 (2016-17 HC 486).

42 https://hansard.parliament.uk/Commons/2018-01-17/debates/0A490445-C4BD-46CE-8E33DFD9B6AA5872/Engagements .

${ }^{43}$ Article 72 (1) (d) (ii) Directive 2014/24/EU of the European Parliament and of the Council of 26 February 2014 on public procurement and repealing Directive 2004/18/EC.

${ }^{44} \mathrm{~J}$. Coley, 'Carillion Q\&A: The consequences of collapse and what the government should do next', The Conversation, 20 January 2018.

45 Public administration and constitutional affairs committee, Sourcing public services: lessons learned from the collapse of Carillion inquiry, 15 January 2018.

${ }^{46}$ On the principle of "social learning": see T. Prosser and L. Butler, 'Rail Franchises, Competition and Public Service', 81(1) Modern Law Review 23-50, 36 (2018). 
Overall, the public-private co-operation in HS2 has led to problems between the public and private partners that are addressed pragmatically by formal and informal bodies or ad hoc techniques. Judges have not been involved so far. Based on previous experiences in England judges would probably only be asked to adjudicate on matters in extreme circumstances. ${ }^{47}$ However, the situation differs when it comes to HS2's external governance, where citizens' opposition has found a range of more or less successful routes, partly hinging on judges to give them some leverage. These techniques are briefly summed up here starting with a more informal procedure.

Firstly, public resistance from individuals/residents' groups along the HS2 route was expressed to the parliamentary ombudsman. In this case a small village had half of its residents expelled whilst the other half were provided with compensatory measures. However, the procedure led to such a breakdown in communication between HS2 Ltd. and the residents that residents complained to the ombudsman. In her report the ombudsman decided that HS2 Ltd. had breached principles of good behaviour and recommended the setting up of a "HS2 resident commissioner" 48 to act as an interface between HS2 Ltd. and local residents. ${ }^{49}$ Since then the commissioner has issued regular updates about the project and HS2 Ltd. responds to the issues the commissioner flags up. For instance, social media is now used to disseminate information to residents about compensation plans available to them. ${ }^{50}$ Here an informal procedure set in motion new ways to reach out to residents and address their questions, hence to contain their opposition and prevent delays in building the project.

Secondly, several freedom of information (FOI) requests were lodged according to the Freedom of Information Act 2000. In one of these, in 2011, a claimant asked for the disclosure of a project management review report drafted by the then Major Project Authority, a unit inside the Cabinet Office. During the course of this request the DfT decided to use a ministerial veto to override the Information Commissioner's decision to allow the disclosure of the document. ${ }^{11}$ Such a veto is only rarely used. The Supreme Court limited the scope of the ministerial veto in a similar case, however, 52 leading the successor of the Major Project Authority, the Infrastructure and Project

47 Such as in the London Underground PPPs, when financial distress led a PPP into administration: third parties (creditors or users) need to be protected and judges are called upon. Procurement is still on-going in HS2 (e.g.: Ted notice published in April 2017, available here: http://ted.europa.eu/TED/notice/udl?uri=TED:NOTICE:151144-2017:TEXT:EN:HTML, invitations to tender expected by April 2018), so it remains to be seen if it will be challenged.

48 Parliamentary and Health Service Ombudsman, Report of the results of an investigation into a complaint about High Speed 2 Ltd (HS2 Ltd) 2015.

${ }^{49}$ HS2 Residents' Charter, available https://www.gov.uk/government/publications/hs2-residents-charter.

50 HS2 Residents' Commissioner, Report 5, September 2016.

51 O. Gay and E. Potton, FoI and ministerial vetoes (House of Commons Library, SN/PC/05007, 2014$) 15$. DfT, Exercise of the Executive override under section 53 of the Freedom of Information Act 2000 in respect of a decision notice of the Information Commissioner dated 6 June 2013 (REF: FER0467548) (https://www.gov.uk/government/uploads/system/uploads/attachment data/file/276159/mpastatement-of-reasons.pdf).

${ }^{52} R$ (Evans) v Attorney General [2015] UKSC 21 [2015] 2 WLR 813. This case involving the disclosure of mail exchanges with the Prince of Wales is not factually connected to the HS2 but the Supreme Court limited the same ministerial veto that was used in HS2. This ministerial veto could be used so that the Attorney General or a Cabinet Minister could override a decision (even a judicial decision) to publish administrative documents. The Supreme Court decided that judicial control could not be set aside by the executive in that way. Subsequently to the Evans decision the judicial review pertaining to HS2 was conceded. J. Milford, 
Authority (IPA), a body reporting to HM Treasury and the Cabinet Office, to release reports pertaining to the HS2.53 In this way judges ensure that new techniques, such as FOI, are made effective and equip citizens and associations with the means to better protect their rights when dealing with public bodies and economic actors.

Thirdly, environmental associations opposing HS2 argued that the European directive on strategic environmental assessment ${ }^{54}$ required an environmental impact assessment to be carried out. The government, however, considered that this was not required at the Command Paper stage of HS2 as the hybrid bill procedure guaranteed enough public participation in the overall process. The claimants asked the Supreme Court to refer the matter to the Court of Justice of the European Union. The Supreme Court declined to do so, considering that the CJEU's previous case law granted domestic courts the power to assess for themselves whether the legislature had appropriate information to assess the impact of the project on the environment. ${ }^{55}$ Therefore, the Supreme Court refrained from interfering with the parliamentary process ${ }^{56}$ as it does not belong to the judiciary to review this cornerstone of the political process in a democracy. ${ }^{57}$

Overall, the HS2 helps us to identify the distinctive contribution of judges in addressing legal issues arising from major infrastructure projects in England. Among the wide range of techniques used to control how public power is exercised, taxpayers' money is spent and private property affected, Parliament features prominently, with the hybrid bill, the PAC, the reports from the ombudsman, and the coordination between the NAO and the DfT. In addition, minor bodies (resident commissioner, construction commissioner) micro-manage disputes at the local level. In this picture judges only have an interstitial role.

Albeit scarce, judicial decisions significantly frame the formal space within which HS2 is decided on and delivered. The Supreme Court has agreed to defer to the legislature where environmental associations can make their position known and provide MPs with appropriate information to help them decide on the project. Yet, it seeks to open up the executive significantly more, and to limit cases when the government can veto the disclosure of administrative documents in the name of public interest. Strategically used in relation to HS2 FOI helps to peel away some aspects of the project so as to bring more administrative documents into the public debate. This means that the Supreme Court seeks to define the judiciary's role in relation to public-private cooperation in line with its overall understanding of power allocation in England, where parliamentary sovereignty ${ }^{58}$ and political accountability when it comes to resource allocation ${ }^{59}$

High Speed Trains and Black Spider Letters: Freedom of Information and the ministerial veto, 20(4) Judicial Review 206, 214 (2015).

${ }^{53}$ See: https://www.gov.uk/government/publications/hs2-major-projects-authority-project-assessmentreview-reports.

${ }^{54}$ Directive 2001/42/EC of the European Parliament and of the Council of 27 June 2001 on the assessment of the effects of certain plans and programmes on the environment.

${ }^{55} R$ on the application of HS2 Action Alliance Limited $v$. The Secretary of State for Transport, [2014] UKSC 3 at [88].

${ }^{56}$ M. Elliott, 'Case comment: Constitutional legislation, European Union law and the nature of the United Kingdom's contemporary Constitution', 10(3) European Constitutional Law Review 379 (2014).

${ }^{57}$ As per $R$ on the application of HS2 Action Alliance Limited $v$. The Secretary of State for Transport, [2014] UKSC 3 at [210]-[211].

${ }^{58} \mathrm{Cfr}$. $R$ (on the application of Miller and another) v Secretary of State for Exiting the European Union [2017] UKSC 5. 
are key. The Supreme Court understands its role as the great clock-maker, ensuring that all the flows of information are working properly in the constitutional and administrative machinery from the administration to Parliament and vice-versa, and from civil society to public actors and vice-versa. Yet, it does not make any substantive or political judgements: it only seeks to ensure that the people in a position to make these political decisions are as well informed as possible and that civil society is not unduly obstructed from fulfilling its role. Although marginally involved, judges have made far-reaching contributions to the debates underlying the HS2 project. Is this also the case in French transport infrastructure projects?

\section{Ecomouv'(France)}

The challenges encountered by French classic administrative law are illustrated with a case study where popular discontent about major infrastructure projects has not been properly addressed. The Ecomouv' project epitomizes the current tension between representative and participatory democracy in France. It superposes two different logics: one logic in which the French Parliament adopted an ecotax with near unanimity in 2009; another logic where street opposition organized by farmers led to the project's cancellation. ${ }^{60}$ This case study helps us to better understand the challenges that French administrative judge faces in retaining and/or redefining their traditional role of shaping long-term contractual relationships between public and private actors. This section maps these challenges within the public scrutiny exercised over French major infrastructure projects.

Since the 1970s France has periodically faced a range of budgetary crises. In the 1980s it first decided to nationalize key parts of its economic and financial sector before privatizing large segments of its economy. In the 2000s innovative techniques aiming to reform French administration were adopted to address chronic indebtedness, including the introduction of public-private co-operation under the form of "partnering contracts". ${ }^{61}$ In parallel with these reforms the EU directive 1999/6262 on the "Eurovignette" was implemented. France then adopted statutes organizing an ecotax and implementing the "polluter pays principle".63 Supported by both the right and left-wing parties in Parliament, this ecological tax was not supposed to be levied by the tax administration but by a sophisticated system involving a private partner through a partnering contract.

Public and private interests converged in this project at different levels. First, it was hoped that this project, operated from Metz, would boost economic development in a region badly hit by economic recession. Secondly, economic actors would develop the infrastructure required to levy this ecotax (portals across France, satellites and communication systems etc.), levy the tax from

${ }^{59}$ Lutton (BC) v Secretary of State for Education [2011] EWHC 217 (Admin) [48]. For a critique regarding such a restrictive conception of judges' constitutional role, see E Palmer, 'Resources allocation, welfare rights - Mapping the boundaries of judicial control in public administrative law', 20 Oxford Journal of Legal Studies 63, 74 (2000).

60 L. Schmid, 'L'exécutif et l'environnement: une spirale de renoncements', 11 Esprit, 5 (2014).

61 Ordonnance nr 2004-559, 17 June 2004 sur les contrats de partenariat, later modified by Loi nr 2008735, 28 July 2008. This framework included various conditions for public-private contracts to be concluded, such as a preliminary assessment, the urgency of the project, its complexity and a cost/benefit analysis. A competitive dialogue procedure was needed to award them.

62 Directive 1999/62/EC of the European Parliament and of the Council of 17 June 1999 on the charging of heavy goods vehicles for the use of certain infrastructures.

63 Art. 11 Loi nr 2009-967, 3 August 2009 relative à la mise en œuvre du Grenelle de l'environnement; art. 153 Loi nr 2008-1425, 27 December 2008 de finances pour 2009 (as amended thereafter). 
lorries (though invoicing or subscription) and then pay the proceeds to the state. This, however, triggered legal questions under French law regarding the transfer of taxation, a sovereign mission, to private actors. In principle a partnering contract cannot delegate sovereign missions to private actors. ${ }^{64}$ Therefore a system reminiscent of how taxation was administered in France prior to the French Revolution ${ }^{65}$ was engineered so that the private contractor would guarantee all the proceeds to which the state was entitled, and the French tax administration would be solely responsible for any coercion of debtors or any measure requiring the use of force. This system also triggered criticisms as it meant that the public sector would lose skills and expertise and become more reliant on economic actors to fulfil its missions (running complex infrastructures, drafting and advising on complex contractual matters). ${ }^{66}$ Boundaries between public and private actors were clearly shifting.

Following a tendering process the French government selected Ecomouv', a consortium of Italian and French firms, as the private contractor in 2011. It signed a contract for 13 years and 3 months, under which the tax was supposed to amount ca. 1.2bn EUR each year and $200 \mathrm{~m}$ EUR was paid to Ecomouv' for its services (app. $20 \%$ of the tax proceeds). However, this contract met with strong resistance from both competitors and road users.

First, disappointed bidders challenged the contract. They argued that the state had been advised by a daughter company of Ecomouv', which was thus involved in a conflict of interests. In the first instance the administrative tribunal terminated the contract for breaching transparency and competition requirements. ${ }^{67}$ However, the Conseil d'Etat ${ }^{68}$ maintained it as the collaboration with the advisor had only been occasional and special care had been taken during the procedure to avoid the decision-making process being unduly biased. This case was important in two respects. First, the Conseil d'Etat applied for the first time a general principle of impartiality in public contracts. Secondly, the type of impartiality that was questioned related to an appearance of partiality flowing from relationships between corporations. It was not a case of personal or subjective partiality manifested by an individual involved in the procedure. The administrative judge in this case declined to quash the decision for breaching the impartiality principle on the basis of circumstantial elements. This balancing between principle and modalities ${ }^{69}$ thus offers a new tool for an administrative judge to assess the awarding of public contracts with due respect to the particular facts of the case, while offering the possibility of fostering a stronger ethic in the public and private actors involved in public contracts. ${ }^{70}$

${ }^{64}$ C.C., nr 2003-473 DC, 26 June 2003, relative à la loi habilitant le Gouvernement à simplifier le droit.

65 Sén., Rapport fait au nom de la commission d'enquête sur les modalités du montage juridique et financier et l'environnement du contrat retenu in fine pour la mise en oeuvre de l'écotaxe poids lourds, (2013-14) t.1, 27-28 (thereafter: Senate Report).

${ }^{66}$ F. Rollin, 'Le contrat de partenariat "écotaxe", symptôme d'un Etat impotent', Actualité juridique - Droit Administratif 2225 (2013).

${ }^{67}$ Trib adm (ord) Cergy-Pontoise, 8 March 2011, Actualité juridique - Collectivités territoriales 297 (2011).

${ }^{68}$ C.É.fr., 24 June 2011, Ministre de l'Écologie, du Développement durable, des Transports et du Logement, Droit administratif nr 84, note J.-B. Auby (2011).

${ }^{69} \mathrm{~A}$. Friboulet, 'Les contours du principe d'impartialité appliqué au controle de la régularité de la procédure de passation d'un contrat public', Revue juridique de l'économie publique, comm. 54 (2011).

70 J. B. Auby, 'Ecotaxe, impartialité de l'administration, conseils', Droit administratif, nr 84, 5-7 (2011). 
Secondly, the contract met with public opposition coming from Britany farmers relying on historic rights to use their roads free of charge, rights dating back to a previous revolt won in 1675 against royal stamp duties. In 2013 these farmers destroyed numerous signal transmitters and checkpoints. As a consequence the Prime Minister first suspended the introduction of the tax, then called it off at the end of the year. He terminated the contract and a transaction ${ }^{71}$ was signed with Ecomouv' to compensate it for the cancellation of the contract. ${ }^{72}$

This solution is striking for technical and symbolic reasons. A statute voted through by Parliament (with the majority of the main political parties) had its implementation suspended by the executive leading to its freezing and eventual abrogation. ${ }^{73}$ Hence, the general will of the French citizens expressed through its legitimate and constitutional institutional voice, Parliament, was set aside by the regional will of a sectoral group acting violently on the streets. The executive ratified the latter against the explicit will of the former. Judges were not involved in any way in clarifying legal matters pertaining to the political choices involved in this case. No judicial redress was relied on. Moreover, judges were even excluded from adjudicating on the cancellation of the contract as the parties agreed to settle, although settlements in French public contracts remain a controversial matter. For instance, this suspicion was illustrated in Ms Lagarde's case: settlements preclude public scrutiny on the agreed terms. ${ }^{74}$

Ecomouv' illustrates the limited extent to which scrutiny can be maintained over public-private co-operation in France. It is true that a range of public bodies, such as the Cour des Comptes, the Sénat and the Assemblée nationale ${ }^{75}$ (respectively the Audit Court, the Higher Chamber and the Lower Chamber), have issued reports on this case. However, little detailed information from the Cour des Comptes is available. The Senate's commission did not benefit from the input of French expert 76 institutions able to advise it on public-private contracts. The Assemblée nationale heard stakeholders and civil servants, with no hearing from the Cour des Comptes or a similar independent expert body able to undertake detailed analysis of the contractual relationship. ${ }^{77}$

${ }^{71}$ Circulaire 6 April 2011 relative au développement du recours à la transaction pour régler amiablement les conflits, JORF n0083, 8 April 2011, 6248; C.É.fr., Étude annuelle 2015 du Conseil d'Etat - L'action économique des personnes publiques (Paris, La documentation française, 2015) 147.

72 Although the circumstances surrounding Ecomouv' may sound extreme the cancellation of major infrastructure projects following strong opposition is not exceptional in France. For instance, the highspeed line between Poitiers-Limoges was cancelled in 2016 (C.É.fr, 15 April 2016, Fédération nationale des associations des usagers des transports). The construction of an airport in Notre-Dame-des-Landes is equally fiercely contentious (Mission de médiation relative au projet d'aéroport du Grand Ouest, Rapport, 2017, available at: https://mediation-aeroport-du-grand-ouest.fr/).

${ }^{73}$ Senate Report 95-96 explains how a legislative provision can be left without concrete implementation by the Executive as long as the Executive does not take the implementing decision and the legislative provision is thereafter abrogated. In the case of the ecotax, the executive left the situation "frozen" until the Parliament eventually abrogated it (by article 84 loi de finances pour 2017, upon an amendment introduced by M. Ferrand et al., $\mathrm{n}^{\circ}$ II-808, 13 Novembre 2016).

74 O. Béaud, 'La condamnation de Christine Lagarde par la Cour de justice', Jus Politicum (http://blog.juspoliticum.com/2016/12/20/la-condamnation-de-christine-lagarde-par-la-cour-dejustice-i/).

75 A.N., Rapport d'information déposé par la mission d'information sur l'écotaxe poids lourds, 14 May 2014, nr 1937 (thereafter: Assemblée report).

${ }^{76}$ It held hearings of a law academic and of an economics academic, experts in PPPs, however. 
The Senate's commission also went to Brussels, Vienna and Bratislava to gain further information.78 No French public body seems to have been able to assist official institutions tasked with public scrutiny of this public-private co-operation. Amidst this dearth of expertise the administrative judge adjudicated on limited questions arising from this contract. The most prominent legal question related to the principle of "impartiality", an issue arising between competing economic actors. The popular opposition did not find any judicial channels through which to express itself.79

Overall, this case illustrates how "force trumps legality". The opponents' force won thanks to the forum offered by the media. The executive checkmated the legislature (in matters of taxation, where normally Parliament is supposed to play a distinctive role), and no judicial review was used by opponents to gain a public forum and enter into a constructive discussion based on rational argumentation and evidence exchanged with public and private actors. This result is especially paradoxical as in this very case one key legal issue was the fear that private actors might use power to coerce tax enforcement, which would have entailed an unconstitutional transfer of power to a private actor. This kind of tension needs to be mapped by the law, especially administrative law, so that constructive solutions are developed to protect the ways in which public actors can take the necessary decisions to invest in infrastructure projects whilst the individual freedom of citizens is duly acknowledged. This would be a continuation of the role it played at the turn of the $20^{\text {th }}$ century when it sought to balance public and private interests in public contracts. Yet, the fragmentation of public scrutiny in France has prevented such a development from happening so far. This situation may evolve, however, as Belgium illustrates.

\section{Belgium: Antwerp Oosterweel}

One major mobility problem in Belgium is the traffic around Antwerp. In 2003 projects were developed to address this in a mobility plan, the so-called Masterplan Mobiliteit Antwerpen (later known as Masterplan 2020).80 This strategy included setting up the Beheersmaatschappij Antwerpen Mobiel (BAM), 81 an arm's-length independent public body that enjoyed wide powers to implement the necessary mobility projects. The most important project, the "Oosterweelverbinding", was the closing of the ring road around Antwerp. It included the construction of a tunnel and a bridge over the Schelde river for more than $3 \mathrm{bn}$ EUR. Developed as a public-private partnership, the project involved the private sector in financing, developing, building and maintaining the infrastructure. Most of the funding would come through BAM thanks to private financing. The project costs would be reimbursed thanks to a toll fee paid to BAM. To comply with European budgetary constraints this project could not increase public debt (the socalled ESR neutrality). Eurostat (the statistical office of the European Union) was asked to issue ex ante opinions related to the impact of the legal and financial structure designed for the

77 The body closest to such a position was the Agence de financement des infrastructures de transport de France. However, its budget was supposed to be covered by the ecotax (Senate Report 430).

${ }^{78}$ Assemblée report 545-6.

${ }^{79}$ In the case of Notre-Dame-des-Landes none of the judicial challenges have been successful so far (Mission de médiation relative au projet d'aéroport du Grand Ouest, Rapport, 2017, Annex 6).

80 https://www.vlaamsparlement.be/dossiers/oosterweel-masterplan-2020-bam; De Oosterweel-Saga, Een onderzoek naar de rol van burgers bij besluitvorming rondom de Oosterweelverbinding, Masterscriptie Bestuurskunde, Universiteit van Tilburg, Tilburgse School voor Politiek en Bestuur, 2012, 76p.

${ }^{81}$ Holding Company Antwerp Mobility; Decreet houdende de oprichting van de naamloze vennootschap van publiek recht Beheersmaatschappij Antwerpen Mobiel (BAM), Official Gazette, 19 February 2003. 
Oosterweel project and the role of BAM. ${ }^{82}$ Adaptations to the project were then made so as to keep it off the public balance-sheet.

The procurement process was started in July 2004. It met with intense resistance from economic actors, citizens and associations. Competitors excluded from participating disputed the awarding procedure. ${ }^{83}$ Associations and citizens challenged the route chosen for the project. ${ }^{84}$ They relied on their right to access administrative documents so that they could collect as much information as possible about the project, the expert studies undertaken to design the route and the figures behind the project. They then used the information to compel public authorities to change fundamental elements of the project.85 Public resistance relied on smart communication campaigns (a song was even written to protest against it ${ }^{86}$ ), petitions, protests and other mediasavvy techniques. This led to a referendum in 2009 which showed that many residents opposed the bridge being built. The Flemish administration then decided to search for alternatives.

Adapting the project from a bridge to a tunnel meant significant changes to the project. This had far-reaching implications for the procurement process, which was at an advanced stage. The preferred bidder had already submitted a planning application, which meant that he had incurred high costs and invested resources to secure this contract. Under procurement law legal issues arose over ascertaining whether the route could be adapted and whether part of the project might still be awarded to the preferred bidder through a settlement. These questions were, however, not submitted to a judge but to the European Commission. The European Commission did not give a green light to awarding the contract to the preferred bidder under these circumstances. Another settlement was thus negotiated between the parties: the preferred bidder renounced a damages action amounting to $323.9 \mathrm{~m}$ EUR and BAM paid him $37.19 \mathrm{~m}$ EUR to compensate for the breaking of the negotiations (calculated on the basis of an extended cost-benefit analysis of this project), and waived the right to use the project design developed for the tunnel for another $5.10 \mathrm{~m}$ EUR.

Thereafter, the project's contractual design and project management were deeply revised. First, the project was put on the market in smaller chunks. Secondly, public participation and negotiations with associations became more intense. In 2017 a compromise was reached and a "future alliance" (toekomstverbond) agreed under the leadership of Alexander D'Hooghe, an architect and MIT professor tasked with the covering of the Antwerp ring road. Further public participation should be carried on in a new co-operation structure where associations will remain partners with the public bodies. Part of the compromise was that associations withdrew from

82 http://ec.europa.eu/eurostat/documents/1015035/2990403/BE-advice-Stat-treatment-OosterweelLink-concession.pdf/2dc34a7a-716b-4aa3-b85f-fdf5602d80d5; icn.fgov.be/sites/default/files/bam 3.pdf; http://inrcontent/uploads/2013/11/jaarverslag-BAM-AV-13.5.2013.pdf. http://www.bamnv.be/wp-

83 I.a. C.É.b, nr. 165.404, 30 November 2006; nr. 166.264, 21 December 2006.

${ }^{84}$ I.a. C.É.b, nr. 232.161, 11 September 2015; nr. 217.777, 8 February 2012.

85 E.g. C.É.b., nr 239.363, 11 October 2017, Verhaeghe and VZW Straatego, regarding the request to disclose email exchanges between BAM and its in-house legal advisor. According to the administrative judge these exchanges pertaining to environmental information are not protected by professional confidentiality so they need to be disclosed.

86 oosterweelverbinding a556e1f9/.

https://www.hln.be/nieuws/binnenland/de-wappersong-protestlied-tegen- 
their pending judicial challenges in this case. ${ }^{87}$ This meant that further judicial control over the agreements reached in this project would be taken away so that the project could no longer be endangered by judicial challenges lodged by associations.

This project led to numerous official reviews. First, the Flemish Parliament followed up on this project with progress reports over the years. At the outset these reports were rather general. However, as time passed they became more extensive and probing. The Rekenhof (Court of Audit) also issued control reports (about the project's relevancy, transparency and reliability) and audited the procurement process in 2007.88 Parliament held various hearings. Furthermore, a special commission created in 2009 considered the speeding up of major infrastructure projects. ${ }^{89}$ Many of its recommendations were implemented in the following years.

This overall dynamic has had far-reaching consequences: the problems that arose in the Oosterweel and similar projects resulted in reforms of proceedings in the administrative justice system (especially the Raad voor vergunningsbetwistingen, an administrative Court in charge of adjudicating legal challenges pertaining to urban permits) and the administrative judge, the Conseil d'Etat. ${ }^{90}$ The overall idea is that judges have to reach fast final decisions: administrative decisions cannot be quashed on mere procedural or formal grounds. Therefore, legal techniques such as the administrative loop (a procedure where the judge asks the administration to correct a procedural defect under specific conditions), the limitation of standing to cases when the claimant has an effective interest in the matter and modulation in the time allowed for judicial decisions by judges have been recently introduced to limit the negative consequences of judicial decisions quashing administrative decisions. ${ }^{91}$

The Oosterweel illustrates that the administration considers that judicial intervention is disturbing and threatening. 92 For instance, the discussion between the administration and the preferred bidder was deliberately kept outside judicial scrutiny through a settlement. In parallel, the Flemish legislature has reformed the statute book to limit the opportunities for citizens and associations to challenge planning permits judicially: a range of public-private co-operations had indeed started to face issues as citizens and associations had started to judicially challenge their planning permits. ${ }^{93}$ Judicial challenges seem, indeed, to have equipped associations with powerful tools to slow down and resist projects, although judicial challenges are only one technique in a wider toolkit. This project illustrates how civil society has become increasingly

${ }^{87}$ http://toekomstverbond.be/. See C.É.b., nr. 239.790, 7 November 2017.

${ }^{88}$ https://www.ccrek.be/Docs/2007 15 Oosterweelverbinding.pdf.

${ }^{89}$ Verslag van de Commissie Investeringprojecten, Naar een snellere en betere besluitvorming over complexe projecten, available at https://docs.vlaamsparlement.be/docs/biblio/opendigibib/monografie/2010/118 eindverslag experten commissie.pdf.

${ }^{90}$ Wet houdende hervorming van de bevoegdheid, de procedureregeling en de organisatie van de Raad van State, Official Gazette, 3 February 2014.

${ }^{91}$ F. Viseur and J. Philippart (eds), La justice administrative (Brussels, Larcier, 2015); M. Van Damme (ed), Hervorming van de Raad van State (Brugge, Die Keure, 2014).

92 http://www.ademloos.be/nieuws/kris-peeters-wil-dat-werking-raad-van-state-wordt-aangepast; S. Bekaert, De Raad van State: Staatsgevaarlijk? Over heden, verleden en toekomst van het administratief contentieux Openingsrede gerechtelijk jaar 2012-2013, available at: http://simonbekaert.be/wpcontent/uploads/2012/07/Openingsrede-21-09-2012.pdf.

${ }^{93}$ Decreet houdende wijziging van diverse bepalingen inzake ruimtelijke ordening, milieu en omgeving, 8 December 2017, Official Gazette, 20 December 2017. 
articulate: it knows its rights and has learned how to make them effective. This also strikingly shows that citizens are searching for ways to voice their positions about the common good (or general interest), about which public bodies are usually making decisions. Once citizens are listened to, they are then happy to let go of their resistance in Belgium. For instance, associations have agreed to commit themselves to the "future alliance" with public bodies while setting aside judges and the potential protection that they may offer to their legal entitlements.

\section{Tensions in public-private co-operation: comparing judicial roles}

This paper analysed the increasing wide role that private actors take over in public-private cooperations such as major infrastructure projects through three case studies, the HS2, Ecomouv' and Oosterweel. In these long-term contracts public bodies take a step back, entrusting private actors with extensive missions such as expropriation (e.g. HS2) and tax collection (e.g. Ecomouv'). Public bodies then seek to develop monitoring systems to ensure that private actors perform their contractual obligations. As the financial stakes of these complex arrangements are high, new techniques for organising the public-private relationships and addressing uprising legal issues are designed.

This paper sought to map the role of judges in adjudicating these legal issues arising between public-private actors and from citizens' opposition to major transport infrastructure projects in three European countries: England, France and Belgium. Its main aim was to analyse how judges' role may have been affected following general trends in administrative changes, such as neoliberal approaches to public intervention in the economy and Europeanisation. The case studies have pinpointed how the general context within which major infrastructure projects are implemented is shaped by legal norms which are increasingly finding their sources outside the domestic legal system and inside the European Union. These legal norms find their application in close connection to domestic administrative law procedures (e.g. environmental assessment, public procurement, Eurovignette, budgetary constraints), however. This general context is also changing as better education of citizens and technological development (e.g. the Internet and social media) influence citizens' expectations and uses of their rights. How do judges police the tensions arising from public-private co-operation and complex long-term contractual relationships? These conclusions map them from a comparative perspective in two steps: firstly, by showing how limited the judges' role is within the overall accountability framework surrounding public action in all three legal systems; secondly, by showing that, despite these limitations, each national system is maintaining a core role for judges, very much echoing the main traditional role of judges in each of the three legal systems.

A major common trend across the three case studies is the limited role judges play in the overall accountability system. Judges are not equipped to adjudicate on complex polycentric matters involving economic, legal, managerial and social stakes altogether. These complex matters indeed fall, by their very nature, more within the political realm than the legal one. Therefore, alternative routes are trodden by citizens. Other preventive or curative, formal and informal techniques are developed. Protests, petitions, public consultations, complaints to ombudsmen etc. are widely used, as well as relying on Parliament, audit courts and a myriad of smaller bodies (formal and informal). Overall, judges do not play a leading role in the accountability system. In theory EU procurement directives are deemed to expand judicial control over procurement procedures. National legislatures seek to reduce overall access to judges, however. In England a range of measures have been taken to that effect such as the drastic reduction in legal aid following the financial crisis or the reform of judicial review from 2013 onwards. ${ }^{94}$ In Belgium new conditions

94 See e.g.: Reform of judicial review: The government response [2013 Cm 8611]. 
have been introduced for residents under which they are allowed to challenge environmental planning permits.

However, differences appear between the case studies regarding the level at which accountability is sought and the nature of techniques developed to address conflicts, revealing the distinctive features of each administrative system. Regarding the accountability level, the HS2 illustrates the importance of engaging at the community level in England to find local solutions on the basis of local needs, within a central framework where financial and technical expertise is available. In France Ecomouv' illustrates the discrepancy between local demands and the national accountability system, deprived of robust institutional expertise. In Belgium Oosterweel illustrates how European institutions are resorting to sorting out technical, financial and legal matters.

Regarding the legal techniques developed to address conflicts, the prevention of conflicts and informal resolution systems receive the highest level of attention in England. In France the situation is more conflictual and political protest is heavily relied on. In Belgium recent examples show a changing mindset when it comes to conflict management and prevention. When conflicts happen the administrative judge is equipped with new tools (e.g. the administrative loop or mediation) to seek constructive solutions and not to merely quash administrative decisions.

If judges' role is overall limited they do, however, retain a distinctive role in addressing tensions between public-private co-operation and public opposition: they act as guardians ensuring that administrative decision-making and political trade-offs occur within the procedures, standards and principles set by the law. The three case studies bring out the three main legal issues that are submitted to judges; namely, freedom of information, environmental assessment and public procurement. Here national distinctiveness remains strong. In England the ordinary judge comes into play. His main role is to ensure that citizens and associations are equipped with the necessary tools to make their position known within the political process, which is agreed to be working properly. When appropriate information is within the public domain it is submitted to public rational debates, ensuring that political choices are made. Judges refrain from entering political adjudication. In France the administrative judge decides on the issues pertaining to major infrastructure projects, especially ensuring that the decision-making process is impartial and not biased by private actors. In Belgium the Conseil d'Etat is the first port of call and also ensures that administrative documents are disclosed. Regional environmental courts are now also involved. The ordinary judiciary keeps its role in adjudicating contractual disputes in the performance phase, and may be called on to do so more than before because relationships between public bodies and citizens and between economic actors and associations are increasingly regulated by contracts. Despite these differences, though, efficient decision-making and judicial decisions are paramount. 95

Overall, this limited case law might be enough for legal scholarship to build a broader framework for policing tensions between public-private co-operation and public opposition to major infrastructure projects. As in classic administrative law judges can only decide incrementally and pragmatically on the matters submitted to them. However, scholarship can build on this case law to provide a conceptual toolkit framing administrative decision-making. Today, it has to develop this by ensuring that judicial scrutiny guarantees a safe discursive space to citizens and associations, answering technical questions such as the general methodologies that public bodies have to follow to evidence their choices, and (re)gaining the public's trust in these matters.

95 E.g.: France: C.É.fr., Danthony, 23 Decembre 2011, commented on in Grands arrêts de jurisprudence administrative (19th edn, Paris Dalloz 2013) nr 118; Belgian administrative loop. 